\title{
Synthesis
}

\section{Sensitivity of the Colorado Plateau to Change: Climate, Ecosystems, and Society}

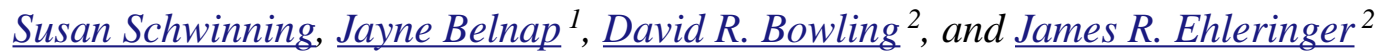

\begin{abstract}
The Colorado Plateau is located in the interior, dry end of two moisture trajectories coming from opposite directions, which have made this region a target for unusual climate fluctuations. A multidecadal drought event some 850 years ago may have eliminated maize cultivation by the first human settlers of the Colorado Plateau, the Fremont and Anasazi people, and contributed to the abandonment of their settlements. Even today, ranching and farming are vulnerable to drought and struggle to persist. The recent use of the Colorado Plateau primarily as rangeland has made this region less tolerant to drought due to unprecedented levels of surface disturbances that destroy biological crusts, reduce soil carbon and nitrogen stocks, and increase rates of soil erosion. The most recent drought of 2002 demonstrated the vulnerability of the Colorado Plateau in its currently depleted state and the associated costs to the local economies. New climate predictions for the southwestern United States include the possibility of a long-term shift to warmer, more arid conditions, punctuated by megadroughts not seen since medieval times. It remains to be seen whether the present-day extractive industries, aided by external subsidies, can persist in a climate regime that apparently exceeded the adaptive capacities of the Colorado Plateau's prehistoric agriculturalists.
\end{abstract}

Key Words: biological crust; climate change; megadrought; ranching

\section{INTRODUCTION: THE COLORADO PLATEAU AS A MODEL FOR GLOBAL CHANGE STUDIES}

Located between the Rocky Mountains of Colorado and New Mexico on the east and the high Sierra Nevada of California on the west, from about $34^{\circ}$ to $40^{\circ} \mathrm{N}$ and $107^{\circ}$ to $114^{\circ} \mathrm{W}$, are the driest regions of the United States (Fig.1). The Colorado Plateau, with its mountains, desert basins, and arid woodlands and grasslands, encompasses the southern Four Corners region of the Intermountain West (southeast Utah, southwest Colorado, northwest New Mexico, and northeast Arizona; West 1988). Known also as cowboy country, this vast region of more than $340000 \mathrm{~km}^{2}$ is used primarily as rangeland, whereas $15438 \mathrm{~km}^{2}$ of National Park lands showcase some of the most spectacular geologic formations of North America. Humans have lived on the Colorado Plateau for nearly 10000 years (Powell and Smiley 2002), but occupation has not been continuous and it is now believed that climate instabilities may have contributed to this interruption in human settlement
(Larson and Michaelsen 1990, Axtell et al. 2002, Coltrain and Leavitt 2002). We suggest that the unique location of the Colorado Plateau at the boundaries of two climate zones may have exposed this region to more extreme fluctuations in climate than other arid regions nearby.

The Colorado Plateau is situated in the interior, dry end of two moisture trajectories of opposite direction (Fig. 2). In summer, this region receives limited moisture primarily as intense, local convective storms. In fall and winter, limited moisture arrives as large frontal systems. Over the last 10000 years, the Colorado Plateau has frequently experienced shifts in the abundance of summer and winter precipitation, likely caused by the geographic displacement of these climate boundaries. These changes have altered vegetation growth patterns and are correlated with both the rise and ultimate disappearance of prehistoric Americans from much of the region (Betancourt et al. 1990, Petersen 1994, Cayan et al. 1999, Salzer and Kipfmueller 2005). 
Fig. 1. The Colorado Plateau. Top inset: climate diagram for the Needles District of Canyonlands National Park, southern Utah. Blue: average daily precipitation, red average daily temperature. Data courtesy of the Western Regional Climate Center. Lower inset: biological soil crust, showing a pinnate crust surface, typical for the Colorado Plateau.

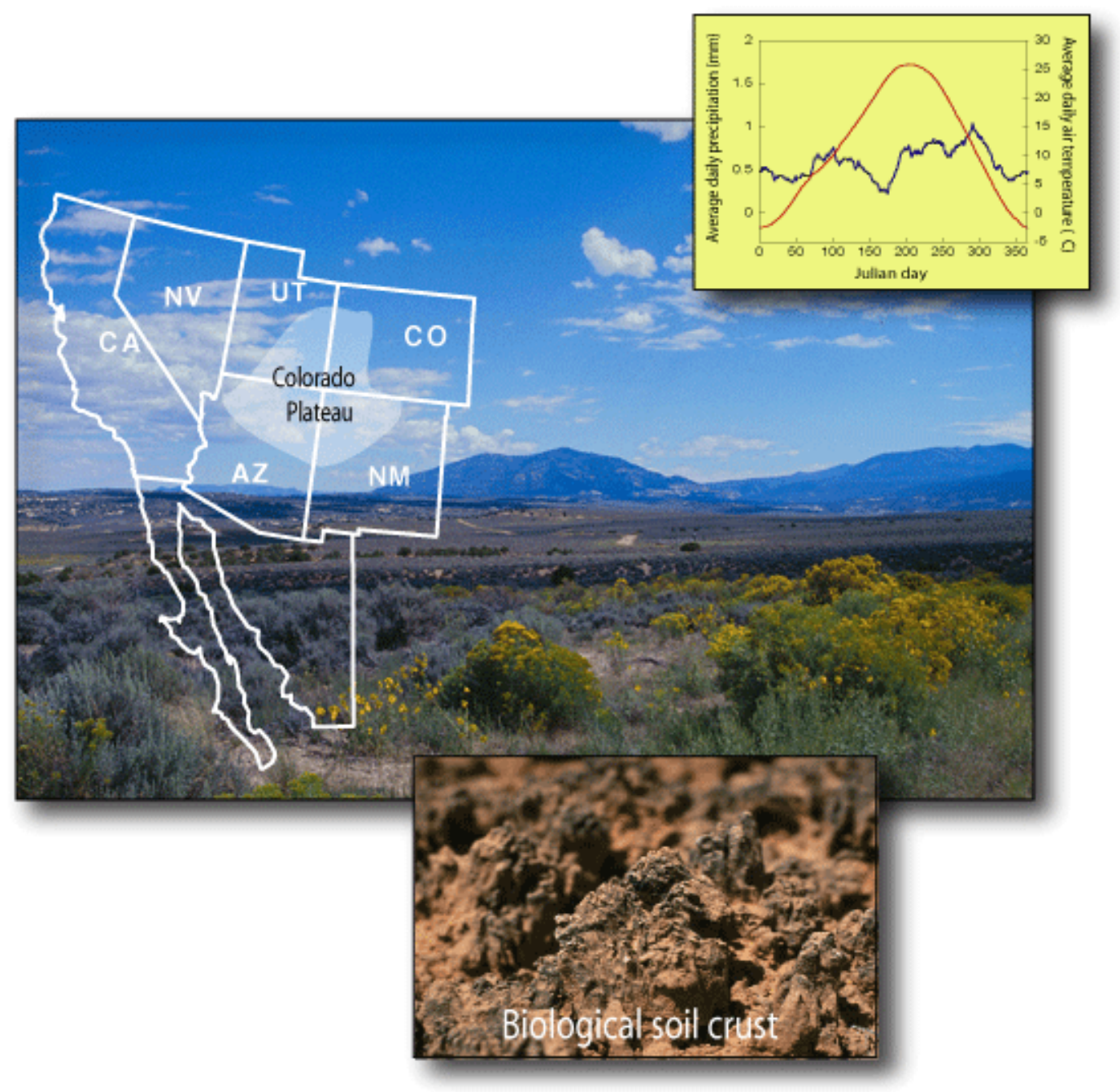

Vegetation patterns on the Colorado Plateau not only follow climatic drivers but also reflect a dominant human impact on the landscape through grazing over the past two centuries (Cole et al. 1997). Even today, Colorado Plateau ecosystems are changing as humans increase use of the most remote regions and invasive species continue to replace native vegetation, altering both fire regimes and the nitrogen $(\mathrm{N})$ and carbon $(\mathrm{C})$ cycles. Here, we describe the sensitivity of this ecological community to change and suggest that, due to its unique location, it may be among the most sensitive of ecosystems to past and current drivers of global change. The Colorado Plateau may, therefore, serve as a model for investigating some of the most challenging questions about the relationships between global change and human affairs: What changes are driven by climate, human land use, and their interactions? How do ecological change and climate variability affect human affairs? How can society build capacity to buffer against the shortterm instability and preserve long-term stability of ecological communities? 
Fig. 2. The Colorado Plateau is located between the dry ends of two moisture trajectories coming from opposite directions (see text for details). Bar charts show average monthly precipitation values from January to December. Inset: maximum percentage of summer precipitation use in three tree species plotted against mean summer precipitation amount at a site (from Williams and Ehleringer 2000, courtesy of The Ecological Society of America). The data suggest a qualitative switch in responsiveness to summer rain across the monsoon boundary.

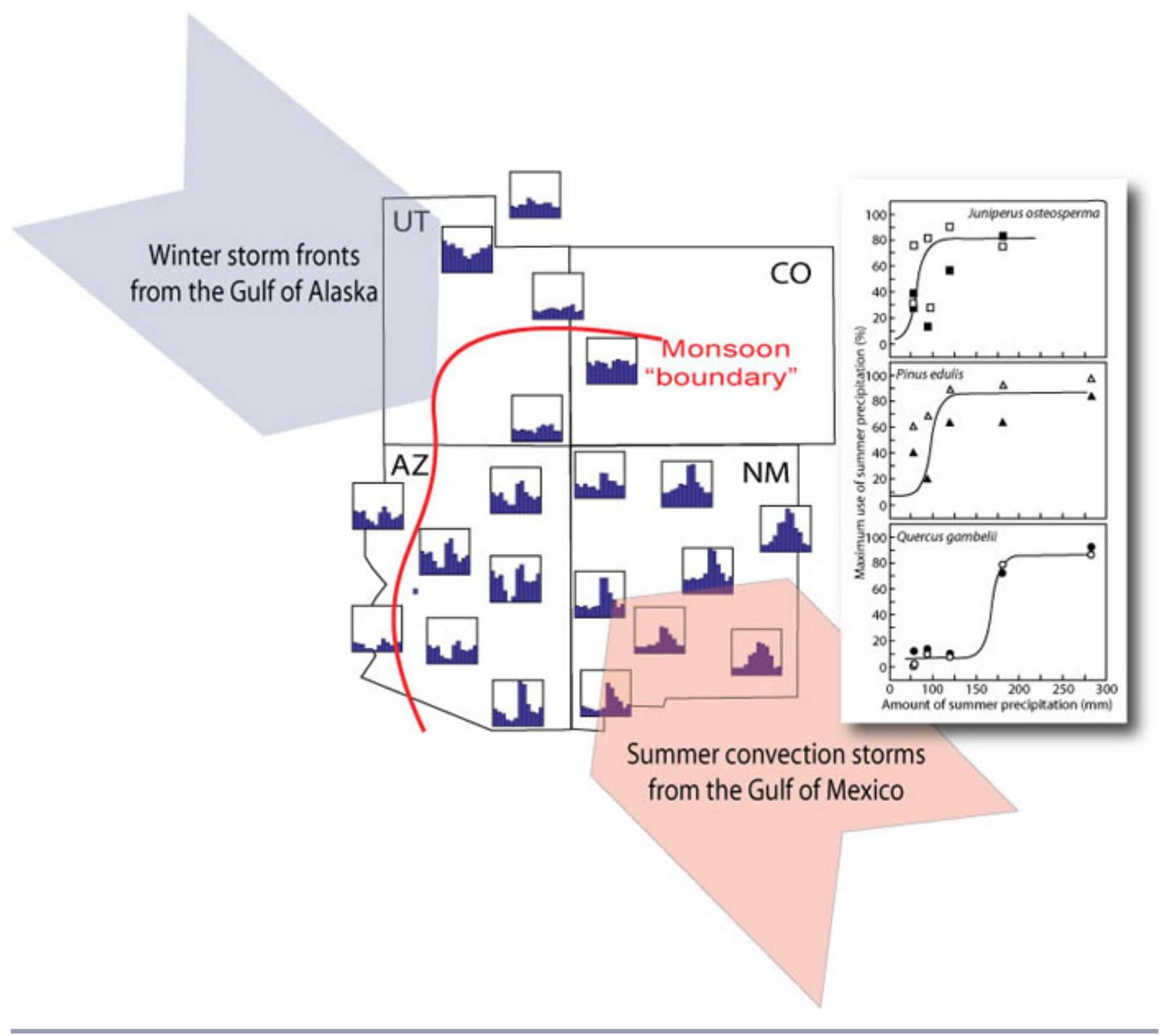




\section{PAST, PRESENT, AND FUTURE CLIMATE OF THE COLORADO PLATEAU}

The climate of most of the Colorado Plateau is classified as semi-arid, with total annual precipitation approximately $250 \mathrm{~mm} \mathrm{yr}^{-1}$, with drier areas in the southern portion receiving as little as $130 \mathrm{~mm} \mathrm{yr}^{-1}$, and higher elevations around the perimeter of the Plateau receiving as much as 670 $\mathrm{mm} \mathrm{yr}^{-1}$ (Hereford et al. 2002). Winters are cold, with moisture coming from the Gulf of Alaska and Pacific Ocean to the north and west. Summers are warm to hot, with a distinct wet period characterized by intermittent but often intense monsoonal storms coming from the eastern tropical Pacific, the Gulf of California, and the Gulf of Mexico (Adams and Comrie 1997, Barlow et al. 1998). Near Moab, Utah, in the heart of the Colorado Plateau, total average annual precipitation is approximately equal to the Great Basin desert to the north and the Chihuahuan and Sonoran deserts to the south. However, the Great Basin desert largely lacks summer moisture, whereas the Chihuahuan and Sonoran deserts have a greater and more reliable summer rainfall component than the Colorado Plateau (Fig. 2). Both winter and summer precipitation are highly variable from year to year. This variability has been linked to El Niño and La Niña patterns (Harrington et al. 1992, Hereford and Webb 1992, Cayan et al. 1999, Cook et al. 2007), although the correlations are modest. La Niña is generally associated with dry winters in the southwest U.S., and El Niño usually (but not always) leads to increased cool-season precipitation (Hereford et al. 2002).

As we explain in more detail below, the current climate of the Colorado Plateau changed about 10 000 years ago from a previously wetter state. The Holocene has been a period of unparalleled climate variability, with frequent multi-decadal excursions from the precipitation means, but no overall trends in aridity. In the last 30 years, the Colorado Plateau has experienced a 0.2 to $0.5^{\circ} \mathrm{C}$ increase, particularly in cold-season temperatures, as typical for the midlatitudes (http://data.giss.nasa.gov), and climate models forecast the continuation of these patterns, but with periodic droughts that will be more severe and possibly longer, due to an overall increase in aridity (Seager et al. 2007).

Paleobotanical evidence from packrat middens on the Colorado Plateau indicates that the current climate pattern has been dominant for at least 10 000 years (Betancourt 1990). However, multi- decadal excursions from the climatic mean have been a common occurrence. Climate reconstructions based on tree ring chronologies (D'Arrigo and Jacoby 1991, Meko et al. 1995, Ni et al. 2002, Gray et al. 2003, Salzer and Kipfmueller 2005, Cook et al. 2007) show that the region experienced several sustained drought periods between the late $10^{\text {th }}$ and mid- $13^{\text {th }}$ centuries, dubbed the medieval megadroughts. Anomalously wet periods were apparent in the early $14^{\text {th }}, 17^{\text {th }}, 19^{\text {th }}$, and $20^{\text {th }}$ centuries. The latter period was one of the wettest in recorded history. The 1905-1922 period had the highest long-term annual Colorado River flow volume in the $20^{\text {th }}$ century and, coincidentally, served as the basis for estimating water production allocated under the Colorado River Compact (http://pubs.water.usgs.gov/fs20043062 ).

Multi-decadal drought cycles (Stahle et al. 2000, Gray et al. 2003, Kitzberger et al. 2007) are linked to the Pacific Decadal Oscillation (PDO; Hereford et al. 2002), which is an index of sea surface temperatures (SST) in the northern Pacific (Mantua and Hare 2002). As SST and related properties (surface winds and air pressure) change in the north Pacific, climate transitions lasting 2-3 decades are observed in North America (Zhang et al. 1997). The PDO, tree-ring records, and measured precipitation are correlated on the Colorado Plateau, suggesting that the geographic locations of climatic boundaries in the American Northwest are influenced by multidecadal global climate cycles, with the Colorado Plateau at the center of the instability.

Five severe, multi-year drought events have been recorded in the western United States in the $20^{\text {th }}$ century: the 1930s' "Dust Bowl," the 1950s' Southwest drought, and the 1980, 1988, and 2002 droughts, the latter having shown signs of ending in 2005 (Cook et al. 2007). All could be attributed to variations of SSTs in the tropics and persistent $\mathrm{La}$ Niña-like patterns (Seager et al. 2007). According to the latest climate forecasts, SST fluctuations will continue to cause drought cycles, but against a background of generally increased aridity caused by changes in atmospheric circulation patterns (Seager et al. 2007). A 19-model consensus forecast for the western United States includes the possibilities of megadrought events by the second half of the $21^{\text {st }}$ century. These droughts are predicted to far exceed the severity of any drought in living memory, including the "Dust Bowl," and may be more akin to the medieval megadroughts. The new predictions suggest that the "Dust Bowl" years may 
better reflect the base condition of the $21^{\text {st }}$ century climate state in the American Southwest, with La Niña patterns creating periodically far drier conditions.

\section{VEGETATION AND ECOSYSTEMS}

Although summer and winter precipitation amounts may be similar, winter precipitation largely determines total annual primary productivity among perennials (Caldwell 1985). Winter precipitation accumulates in the soil due to the low evaporative demand and low transpiration rates at that time of the year. Plants begin to use these soil moisture reserves in early March, when plant growth is triggered by warmer temperatures. By late June, the driest month of the year, reserves of winter soil moisture near the soil surface are largely depleted and shallow-rooted perennial plants go dormant, whereas deeper-rooted plants take up residual water from deeper in the soil profile (Fernandez and Caldwell 1975, Ehleringer et al. 1991). Summer precipitation from late July to mid-September usually creates short pulses of soil moisture that can only be used by plant species that maintain an active shallow-root system, chiefly grasses and latesummer annuals (Ehleringer et al. 1991, Lin et al. 1996, Schwinning et al. 2003).

The vegetation of this region has been previously reviewed (Caldwell 1985, West 1988, Comstock and Ehleringer 1992). In the subalpine regions of the tallest peaks, Engelmann spruce (Picea engelmannii) and subalpine fir (Abies lasiocarpa) are common. With decreasing elevation, these communities transition into a mixed-conifer forest with Douglas fir (Pseudotsuga menziesii), white fir (Abies concolor), Colorado blue spruce (Picea pungens), and finally ponderosa pine (Pinus ponderosa). Between 2100 and $1600 \mathrm{~m}$, pinyon/ juniper woodlands dominate (Pinus edulis, Juniperus osteosperma, and on the southern edge of the Plateau, J. monosperma). Lower in elevation, and occupying most of the Colorado Plateau, is desert scrub, a mixed community of mostly low evergreen or winter-deciduous shrubs and perennial grasses. Sagebrush species (Artemisia tridentata, $A$. tridentata ssp. vaseyena, $A$. wyomingensis) are found at the higher ranges of the shrubland. At lower elevations, the dominant plants include blackbrush (Coleogyne ramosissima), Mormon tea (Ephedra viridis and $E$. torreyana), saltbush (Atriplex canescens, A. confertifolia and A. garrettii), and winterfat (Ceratoides lanata). Many of these shrubs were already present during the last glacial cycle, although displaced to lower elevations (Betancourt 1990). The many grass species of the Colorado Plateau include the $\mathrm{C}_{3}$ Indian ricegrass (Stipa hymenoides) and needle-and-thread grass ( $S$. comata) and the $\mathrm{C}_{4}$ Bouteloua gracilis, B. eriopoda, Sporobolus cryptandrus $S$. airoides, and galleta (Hilaria jamesii).

Notable changes in species composition occurred 200-150 years ago, coincidental with the introduction of sheep and cattle grazing (Cole et al. 1997). Especially palatable species, such as winterfat and ricegrass, declined, whereas species previously absent from packrat midden records and indicative of overgrazed range, increased (Cole et al. 1997). These included snakeweed (Gutierrezia sarothrae), viscid rabbitbrush (Chrysothamnus nauseosus), Russian thistle (Salsola tragus), and cheatgrass (Bromus tectorum).

The landscapes of the Colorado Plateau evolved under low or sporadic grazing pressure. Evidence for this includes the lack of dung beetles, a dominance of grasses that are intolerant of grazing, and soils that are highly vulnerable to erosion when trampled (Mack and Thompson 1982). Bison (Bison bison), although present in surrounding areas during the Holocene, were absent from the Colorado Plateau (Mack and Thompson 1982, van Vuren and Dietz 1993). Limited surface water and forage kept native ungulates such as pronghorn (Antilocapra americana) and mule deer (Odocoileus hemionus) numbers low and at higher elevations, except during some winters when snow provided a water source at lower elevations.

Repeat photographs comparing today's landscapes with those of 100 years ago show that most native ecosystems did not change during this interval and many individual shrubs and grasses photographed in 1898 are still alive and the same size today (Hart and Laycock 1996, Webb et al. 2004). Mortality rates estimated from repeat photographs indicate that many woody shrubs can probably live well over 100 years, and some perennials considered short lived under range conditions can live 70-100 years (Bowers et al. 1995).

The presence of $\mathrm{C}_{4}$ grasses on the Colorado Plateau scrublands is of particular interest, as these species tend to be found where summer rains are reliable. During the last glacial cycle, $\mathrm{C}_{4}$ plants were absent 
from the Colorado Plateau, but present in the adjacent warm Chihuahuan and Sonoran Deserts (Connin et al. 1998). This has led to speculation that monsoonal flow of summer precipitation to the Colorado Plateau may have been suppressed during the last Ice Age (Anderson et al. 2000). Subsequently, a period of particularly strong summer rains that peaked 9000 years ago may have been responsible for the rapid expansion of $\mathrm{C}_{4}$ grasses in the lowlands and, in the higher elevations, of ponderosa pine (Betancourt 1990).

Multi-decadal patterns of drought and highmoisture periods (Gray et al. 2003, Hereford et al. 2002) may have been associated with the waxing and waning of particular vegetation components and overall plant cover, but did not fundamentally reorganize this community. Decadal droughts have influenced fire frequencies, insect outbreaks, woody encroachment, and plant mortality (Swetnam and Betancourt 1998). The 2002 drought has resulted in mass die-off of pinyon and ponderosa pine, as well as high mortality in shallow-rooted species such as yucca and cactus (Breshears 2006, Belnap pers. obs.). Historic droughts may have also led to shifts in ecosystem boundaries (Allen and Breshears 1998). Anomalously wet periods, such as the post-1976 period, have promoted seedling establishment and the vigorous growth of existing shrubs (Swetnam and Betancourt 1998).

Plants of the Colorado Plateau all respond to winter precipitation, but responses to summer precipitation vary (Ehleringer et al. 1991, Flanagan et al. 1992, Lin et al. 1996, Gebauer and Ehleringer 2000, Schwinning et al. 2002, 2003, West et al. 2007a, 2008). In general, the most deep-rooted species are least responsive to summer rain, among them viscid rabbitbrush, winterfat, and shadscale (Atriplex confertifolia). A widely distributed class of vegetation with dimorphic root systems (a shallow, spreading root system combined with a moderately deep taproot) - including blackbrush, snakeweed, and sand sagebrush (Artemisia filifolia)-have intermediate use of summer rain. It has been suggested that this root distribution optimizes the plant's ability to rapidly switch between deeper and shallower water sources according to availability (Schwinning and Ehleringer 2001). Grasses use the most summer rain, but where grass cover is sparse, particularly where livestock grazing occurs, shrubs and subshrubs with dimorphic root systems are probably the greatest consumers of summer rain water at the ecosystem level, provided rain events exceed $10 \mathrm{~mm}$ (Schwinning et al. 2003).
Trees to the south of the monsoon boundary tend to have higher capacities for the uptake and utilization of summer precipitation than conspecifics to the north (Fig. 2 inset). This suggests that there may be a minimum amount of summer rain required for changing rooting patterns to occur, whether phenotypically or genetically, and that the minimum for pinyon pine and juniper is between 100 and 150 $\mathrm{mm}$ (Williams and Ehleringer 2000, West et al. 2007a, 2007b, 2008). Below this threshold, surface roots may be too costly to maintain through dry periods and plants may lose more $\mathrm{C}$ than they would gain on average if they responded to summer rainfall (Schwinning and Sala 2004).

\section{THE SPECIAL ROLE OF BIOLOGICAL SOIL CRUSTS}

Soils between the widely spaced vascular plants on the Colorado Plateau are generally dominated by a community of cyanobacteria, microfungi, lichens, and mosses collectively known as biological soil crusts (BSCs; Fig. 1, inset). Biological soil crusts dominate the landscape in this region, can represent up to $70 \%$ of the living cover (Belnap 1995), and can heavily influence system function in most ecosystems (Fig. 3). The presence of BSCs is critical for soil fertility, moisture, and stability in this region. Like the higher plants of the Colorado Plateau, the timing and rates of physiological activity of the BSC are governed by rainfall inputs and temperature. Biological soil crusts are active whenever wet, and unlike plants, can respond to even $1-\mathrm{mm}$ rain events.

Biological soil crusts are an important source of C for subsurface soil organisms in these ecosystems, as soil C is limited in desert soils (Belnap 2003a). Whenever dry crusts are wetted, there is an immediate respiratory burst of carbon dioxide $\left(\mathrm{CO}_{2}\right)$ as well as a 30-60 min time lag before respired $\mathrm{C}$ can be replaced by photosynthesis (Lange 2003; Lange et al. 1996, 1997). To compensate for this initial loss, and thus maintain a positive $\mathrm{C}$ balance, the soil surface must remain wet for an extended period of time during the day, a condition most likely to be satisfied in late fall through spring when air temperatures are cool.

Summer rains can be problematic for BSCs. Whereas higher plants can control their physiological response to rain in summer to avoid possible C losses, BSCs have no such control and summer rains usually result in rapid wetting and 
Fig. 3. Interactive pathways between climate, ecosystem, land use, and economy (see text for details).

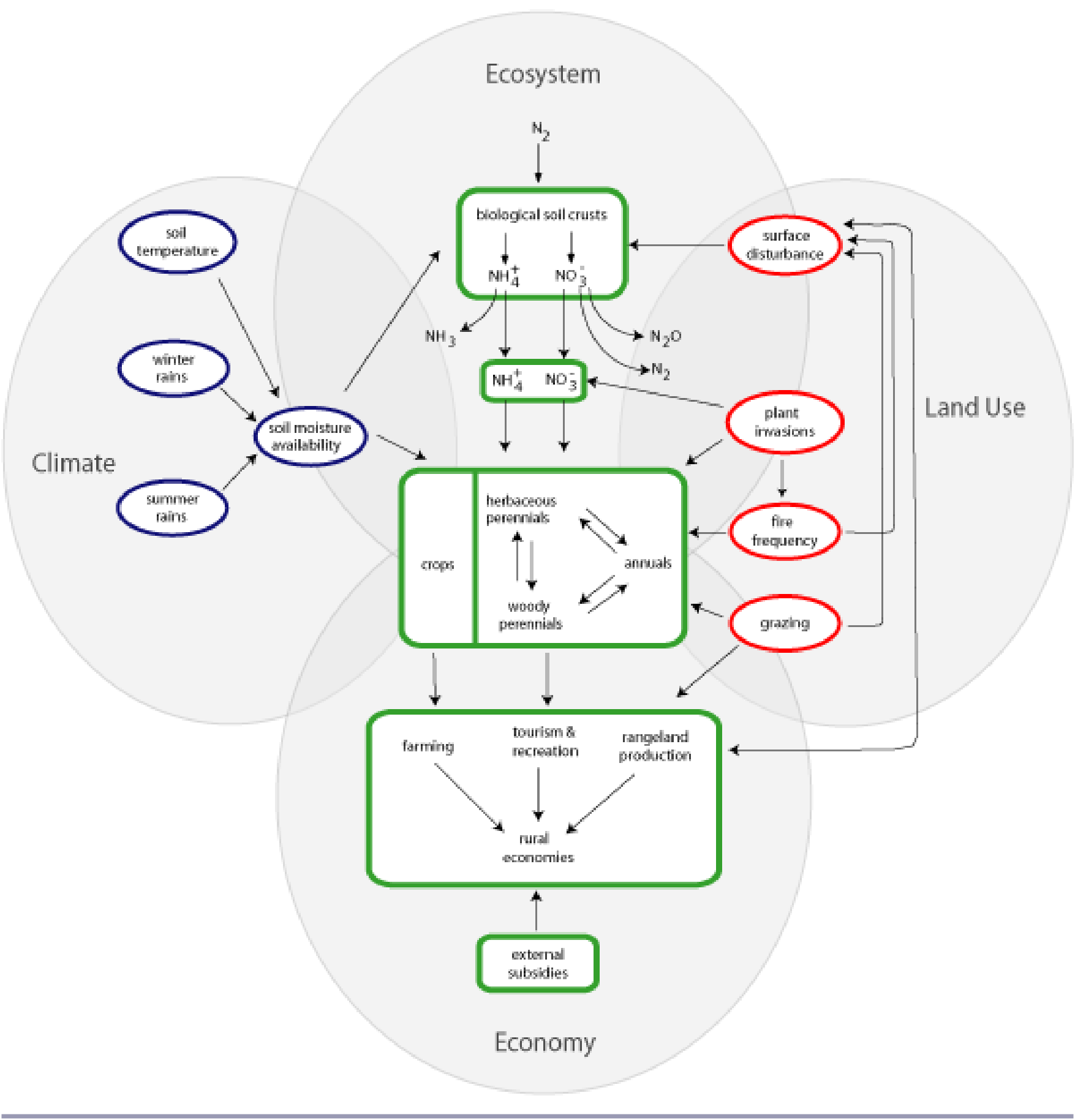


drying cycles. If BSCs dry too soon, they cannot replace the $\mathrm{C}$ lost during wetting, and $\mathrm{BSC}$ organisms suffer $\mathrm{C}$ deficits as a consequence (Belnap et al. 2004, 2006). Net C gain in summer, given high air temperatures, requires precipitation events greater than $3 \mathrm{~mm}$, yet more than $70 \%$ of all rainfall events in summer are below this threshold (data courtesy of U.S. Geological Survey Clim-Met, specifically Site \#8 at Corral Pocket, southern Utah, $\left.38^{\circ} 09.687^{\prime} \mathrm{N}, 109^{\circ} 39.568^{\prime} \mathrm{W}\right)$. Furthermore, rainfall events at night will result only in respiratory $\mathrm{C}$ losses and no $\mathrm{C}$ gains, and up to $70 \%$ of rainfall events in summer occur at night.

Free-living and lichenized cyanobacteria (e.g., Nostoc in soil and Nostoc in the lichen Collema) provide the largest $\mathrm{N}$ input for Colorado Plateau soils (Evans and Ehleringer 1993, Evans and Belnap 1999). Nitrogen fixation only occurs when the cyanobacteria or lichens are wetted and have sufficient $\mathrm{C}$ compounds to act as electron donors (Paul and Clark 1996). Thus, the rainfall requirement for $\mathrm{N}$ fixation exceeds the requirements of net $\mathrm{C}$ fixation. With sufficient moisture and $\mathrm{C}$ stores, $\mathrm{N}$ fixation rates are controlled by temperature. As with $\mathrm{C}$, most $\mathrm{N}$ fixation occurs between $-5^{\circ} \mathrm{C}$ and $30^{\circ} \mathrm{C}$, with the optimum at 20 $25^{\circ} \mathrm{C}$ (Belnap 2003a). Estimates of annual $\mathrm{N}$ fixed on the Colorado Plateau range from $1-9 \mathrm{~kg} / \mathrm{ha} / \mathrm{yr}$, depending on BSC composition (Belnap 2002). Up to $70 \%$ of the newly fixed $\mathrm{N}$ is released from the BSC organisms and is readily taken up by surrounding organisms, including vascular plants, fungi, actinomycetes, and bacteria, as well as reabsorbed by the releasing cyanobacteria or lichen (reviewed in Belnap 2003b).

Like C, most $\mathrm{N}$ is fixed September-May. Winter fixation rates are aided by the dark color of BSCs, which by enhancing absorption of solar energy can increase their temperature as much as $14^{\circ} \mathrm{C}$ on sunny days (Belnap 1995). Due to cold subsurface soils, gaseous $\mathrm{N}$ losses are minimal during this time (Barger et al. 2005). Thus, soil $\mathrm{N}$ levels build up over fall and winter and peak in spring, when the demand and uptake capacity of native vascular plants and microbial populations is maximal (Gebauer and Ehleringer 2000, Schwinning et al. 2005). In summer, high soil temperatures preclude $\mathrm{N}$ fixation and facilitate gaseous loss, although losses are still relatively low $(<1 \mathrm{~kg} / \mathrm{ha} / \mathrm{yr}$; Barger et al. 2005). Biological soil crusts affect the availability of soil nutrients in other ways as well (Belnap 2003b). They secrete powerful metal chelators and other substances that help maintain nutrients in plant-available forms, important in these high $\mathrm{pH}$ desert soils. They facilitate the formation of soil aggregates, and soil faunal abundance and richness is greater under crusted surfaces than non-crusted surfaces. Thus, their presence enhances $\mathrm{C}$ and nutrient transformation rates. They greatly roughen the soil surface (Fig. 1, inset), increasing the retention of seeds, organic matter, and nutrient-laden dust (Belnap et al. 2003). As a result, plants growing in crusted soils often have greater productivity and higher leaf nutrient concentrations than plants growing in adjacent, uncrusted soils.

Although BSCs are critically important in C and $\mathrm{N}$ cycles in this region, their greatest contribution to ecosystem health and the maintenance of soil fertility may be due to their impact on soil physical properties. By binding together soil particles and increasing the formation rate and size of soil aggregates, they increase soil aeration and porosity while drastically reducing both wind and water erosion rates (Belnap and Gardner 1993). Their roughened surface slows runoff of precipitation and thus increases infiltration into the soils (Warren 2003). They also "cap" the soil surface, retarding evaporation and thus increasing soil moisture retention times (George et al. 2003).

\section{HUMAN IMPACTS}

In prehistoric times, the agricultural settlements of the ancestral Pueblo people on the Colorado Plateau coincided with the Medieval Warm Period (800 1300 AD), a warm period that, during its height, extended the growing season and increased both winter and summer precipitation (Petersen 1994). This climate opened opportunities for dry farming of maize at elevations between 1600 and $2300 \mathrm{~m}$. Reconstructed household numbers in the Long House Valley in the Black Mesa area demonstrate 300 years of population increases, followed by 200 years of relative stasis, and then a sudden collapse at the height of the Little Ice Age around 1300 (Axtell et al. 2002), which would have closed the dry farming belt in upland areas (Petersen 1994). The Medieval Warm Period was also associated with several megadrought events (Cook et al. 2007), the last one peaking in 1253, shortly before the collapse of the Pueblo culture on the Colorado Plateau. 
The Medieval Warm Period was followed by the Little Ice Age, and when it ended in the 1800s, human settlers returned to the Colorado Plateau (Petersen 1994). The new settlers were Anglo farmers, who brought sheep and cattle and began dry-farming beans, winter wheat, and, to a lesser degree, fruit in the upland belt (2000-2300 m). Mining of ore deposits occurred where local geology allowed it.

When the Mormon pioneers arrived in Utah in 1847 , they encountered a perennial grass-dominated landscape with few native herbivores. Within a short time after their arrival, grazing by their livestock converted the areas surrounding and connecting settlements into shrublands generally dominated by sagebrush (Cottam 1948). The anomalous wet period in the early 1900s coincided with, and likely aided, an unprecedented expansion of ranching and farming throughout the western U.S.

Grasslands recover from overgrazing slowly and incompletely. In a field study at the Desert Experimental Range in southwestern Utah, vegetation took 59 years to recover from a shrubdominated, heavily overgrazed state in 1935 to a state where grass cover only slightly exceeded shrub cover in 1994 (Alzerreca-Angelo et al. 1998). Reduced grazing pressure and a wetter climate led to consistently increasing grass cover over the entire 59-year study period, but shrub cover changed only slowly with an initial increase and a slow decline only after 25 years of decreased grazing pressure. Currently, almost $90 \%$ of the Colorado Plateau is used by the ranching industry, but cattle densities are low compared with the early $20^{\text {th }}$ century, as it frequently takes up to 60.7 ha (150 acres) or more to support one animal. The current year-round human population size on the Colorado Plateau is about 2.1 million (U.S. Census Bureau, 2005 estimate), and in 2001, there were 733000 head of cattle (USDA National Agricultural Statistics Service), reduced by the 2002 drought to 498000 . The Colorado Plateau now also supports vast deer herds. Whereas in 1900, the deer population was an estimated 8000 animals (Cottam 1948), in the 2002 drought year, the Utah Division of Wildlife estimated the population at 425000 animals with a "target" population of 450000 animals (Utah Division of Wildlife, pers. communication to Belnap, 2002). Deer numbers have increased dramatically due the development of surface water sources, the invasion of sagebrush, the removal of natural predators, and a demand from the hunting public for high hunting success rates. To increase hunting opportunities, the Utah Division of Wildlife also transplanted Rocky Mountain elk into Utah. The current herd size of 60000 animals (Adams 2005) further contributes to the grazing and trampling pressure on these landscapes.

High animal numbers and chronic trampling and herbivory have had profound impacts on Colorado Plateau ecosystems (Fig. 3). Grasslands have been converted into sagebrush-dominated landscapes and BSCs have been severely impacted. Although BSCs have high tensile strength, they have little resistance to the shear and compressional forces generated by trampling or vehicle use. Lichens and mosses, the BSC components that contribute the most to soil fertility and stability, are also the first BSC components to be lost (Belnap and Eldridge 2003). The subsequent loss of $\mathrm{C}$ and $\mathrm{N}$ inputs, resource capture, and soil stability has reduced soil fertility. Studies show a consistent 40\%-70\% reduction in soil $\mathrm{C}$ and $\mathrm{N}$ when low-elevation areas currently grazed by livestock are compared with nearby areas that have never been used by livestock (e.g., Neff et al. 2005, Fernandez et al. 2006). Grazed sites have up to $40 \%$ less silt (and thus less water-holding capacity) and up to $50 \%$ less total elemental soil magnesium $(\mathrm{Mg})$, sodium $(\mathrm{Na})$, phosphorus $(\mathrm{P})$, and manganese $(\mathrm{Mn})$ contents relative to soils never exposed to livestock disturbance. In addition, soil organic matter in this region has a fast turnover time. Soil $\mathrm{C}$ disappears quickly when plant biomass is reduced by heavy grazing.

Other human activities in this region have exacerbated the effects of livestock grazing and high deer populations. Energy exploration and recreation (e.g., hiking, camping, mountain biking, off-road vehicle recreation) are increasing exponentially, and often occur in areas not previously impacted by livestock, as humans are not limited by naturally occurring food and water sources. This has resulted in large amounts of additional soil disturbance, further reducing BSC cover in this region, with an attendant reduction in soil fertility and stability. Areas heavily used by recreationists for 5-10 years often show greater resource loss than landscapes grazed by livestock for over 100 years.

Thus, the widespread surface disturbance in this region will continue to reduce the ability of these lands to support current plant communities and the wildlife and livestock that depend on them. As BSC 
cover declines, $\mathrm{N}$ inputs into the soils decline and loss rates increase, thus reducing the $\mathrm{N}$ content of both soil and plants (Evans and Belnap 1999). These losses are long term (Evans and Belnap 1999) and, even though arid and semi-arid lands are primarily limited by water, rangeland forage production is often limited by soil nutrients, particularly in higher than average rainfall years (Guevara et al. 2000). Because of the slow recovery of lichens and mosses in this region (>250 years; Belnap et al. 2003) and soil formation rates (5000-10 000 years; (Dregne 1983), areas receiving intense or chronic soil disturbance should be considered more or less permanently impaired.

In addition to surface disturbance, human-related activities have other consequences as well. Seeds of exotic invasive annual grasses are spread by livestock and vehicles, and their germination is enhanced by soil surface disturbance (e.g., Belsky and Gelbard 2000). In addition, livestock herbivory reduces the ability of native plants to compete with the less-preferred exotic annual grasses, resulting in the loss of the perennial component. During drought years, these annual grasses often fail to germinate or do not grow well (Belnap et al. 2006), leaving the soil surfaces highly vulnerable to erosion. Dust collection networks show that if annualized areas are also grazed, soil loss via wind erosion can increase several orders of magnitude over noninvaded, non-grazed areas (Belnap, unpublished). Conversely, in wet years, these annual grasses create continuous fuels that carry fire. Despite examination of hundreds of soil pits scattered throughout the landscape, we have not found charcoal or any evidence of widespread fires occurring in the low-elevation communities of this region. Present-day fires generally result in the widespread mortality of native perennials. Periods of sustained drought can lead to widespread wildfires at mid-elevation in this region that supports pinyon, juniper, and pondersosa pine, generally following the death of the trees from insect infestation (Cook et al. 2004, Kitzberger et al. 2007). The combination of increased temperatures and earlier springs has also increased fire frequencies in this region (Westerling et al. 2006).

\section{ECONOMIC AND ECOLOGIC BUFFERING AGAINST CLIMATE INSTABILITIES}

The traditional industries of the Colorado Plateau are extractive, and with the exception of mining, depend directly on adequate rainfall. One of the strongest constraints on these industries is the occurrence of drought years, which push agriculture to the brink of bankruptcy and often beyond. Farming economies have developed mechanisms to buffer against this inevitable production variability and uncertainty, allowing them to store the advantages gained in good years to sustain themselves through bad years. This dependence on rainfall was also experienced by the prehistoric occupants of the Colorado Plateau, although they used different mechanisms to buffer against the consequences of a variable year-to-year climate.

The earlier settlers of the Colorado Plateau lived in family and small village units that were probably self-sustaining. Their increasing wealth and population expansion were associated with successful and expanding maize cultivation. During drought periods, people relied on stored grain, and may have increased consumption of wild-plant products, such as rice grass seed, pine nuts, acorns, and tubers, and animals. Isotopic evidence from analysis of human tooth enamel suggests that by the end of the prehistoric occupation of the Colorado Plateau, near the peak of the last medieval megadrought around 1250, cultivated maize had dropped entirely from the diet and people ate predominantly wild plants (Coltrain and Leavitt 2002). The absence of external subsidies did not allow the earlier agriculturalists to extend extractive efforts beyond the level supported by the local environmental conditions. Although irrigation agriculture was practiced, it too depended on the flow-regime of local rivers and streams, which would have declined under persistent drought conditions. In addition, some argue that centuries of maize cultivation and deforestation may have compromised the productivity of the region and with it the abundance of wild foods (Redman 1999). With limited ability to store grains and find wild foods, the buffering capacities of the early Pueblo people may have become overwhelmed, ushering in the abandonment of the Colorado Plateau region and supposed southward migration into more mesic regions in southern Arizona and along the Rio Grande (Nelson and Schachner 2002).

The Anglo settlers of the Colorado Plateau were no less challenged by climate variability and weather extremes. The $20^{\text {th }}$ century has been marked by five extreme droughts and many locally devastating floods (Wilkowske et al. 2003). Although periodic droughts on the Colorado Plateau were not as 
devastating as the famous Dust Bowl years in the Great Plains (in fact some Dust Bowl refugees resettled on the Colorado Plateau; McPherson $1995)$, history books provide a view of the early $20^{\text {th }}$ century replete with stories of crop failures, livestock loss due to drought, fire, or cold weather, and the abandonment of whole towns (Firmage 1996). For example, when sheep production failed due to drought and range degradation, the town of Cisco, Grand County, Utah, went from a population size of 323 in 1910 to a population of 95 in 1920. In 1910, Grand County had 172 farms with 62089 cultivated acres; by 1920, only 114 farms were left with 42656 cultivated acres, and the numbers continued to decline (Firmage 1996).

Irrigation agriculture was often compromised not only by drought, which failed to fill reservoirs and reduced stream flows, but also by flood years, which destroyed irrigation infrastructure. In the 1930s, government policies encouraged homesteading, and many Dust Bowl refugees started dry wheat farming in SE Utah. However, in 1934, the worst recorded drought hit the Colorado Plateau, leading to total wheat crop failure and many homesteads were abandoned. The period from 1905 to 1941 was followed by an even drier period with a new record drought in 1956 (Hereford et al. 2002).

Today, dry crop productivity still follows rainfall (Fig. 4), but there is no close correlation between precipitation and cattle numbers, suggesting that today's ranchers use economic reserves (e.g., bank accounts) and government subsidies to keep cattle numbers constant and within a profitable range. Government assistance during drought years includes support for fencing, water developments, roads, and occasionally, animal feed. Figure 4 also demonstrates the negative correlation between farm subsidies and precipitation, along with an overall increasing trend in subsidies since the mid-1960s. Government payments reached an unprecedented high during the 2002 drought, the worst drought year since the mid-1970s. Although cattle numbers declined after 2002 , the $17 \%$ decline relative to the previous 5-year average for southern Utah $(33 \%$ across the entire Colorado Plateau) is small compared with the severity of the drought, which rivals the drought of 1934 (Wilkowske et al. 2003). Thus, government subsidies and economic reserves appear to be used to stabilize herd sizes, and thus income, against precipitation variability.
Although it is clear that both ancient and modern farmers share the need to buffer against primary productivity cycles by building economic (or food) reserves during "good" years, it is often overlooked that ecosystems need to do the same by building ecological reserves (Fig. 5). Extractive uses of primary production compete with what Noy-Meir (1973) coined "plough-back," or the reinvestment of primary productivity into ecosystem reserves, which enables ecosystems to respond strongly to the next rainy season. The ability of an ecosystem to respond can be expressed as the ratio of primary productivity to rainfall input, the so called "rain use efficiency" (RUE, Le Houérou 1984). Reserves that can affect RUE include soil nutrients, soil organic matter, belowground $\mathrm{C}$ storage in plant roots and tubers, meristems, and especially BSCs, which greatly reduce erosion potential during drought or flood years. All of these forms of reserves are negatively impacted either directly or indirectly by extractive land uses. Without careful management of extractive effort in relation to drought cycles, ecological reserves decline and RUEs will drop further, ultimately reducing both economic and ecological reserves.

Much depends on the use of economic reserves. The western United States has had a long history of policies that encourage the maintenance of excessively high extractive effort (Hess and Holechek 1995). Government subsidies have boosted economic reserves and allowed the maintenance of extractive efforts (e.g., livestock herd sizes; oil, gas, and mining exploration and development; water developments, such as dams and canals) beyond ecologically sustainable levels. Particularly damaging may be the speed with which farms return to "normal" activity (e.g., herd sizes) after drought through improved transportation, larger economic reserves, and the ability to import livestock or other goods from afar through the North American Free Trade Agreement (Thurow and Taylor 1999). Both, a delayed management response at the onset of drought and the accelerated return to "normal," take away from ecological reserve building.

The evidence that high and chronic levels of herbivory and surface-disturbing activities have negatively impacted the ecological reserve status of the Colorado Plateau, through a reduction in plant and soil storage of $\mathrm{C}$ and nutrients, is strongly supported by many studies (e.g., Neff et al. 2005, 
Fig. 4. Farm trends in the Utah section of the Colorado Plateau. A: Dependence of dry-land farming (wheat), cattle numbers, and government payments on September to May precipitation (data source: U. S. Department of Agriculture, Agricultural Statistics Service). Precipitation data are the averages of six precipitation records across the Utah portion of the Colorado Plateau (data courtesy of the Western Regional Climate Center). B: Farm income trends (data source: U.S. Department of Commerce, Bureau of Economic Analysis).

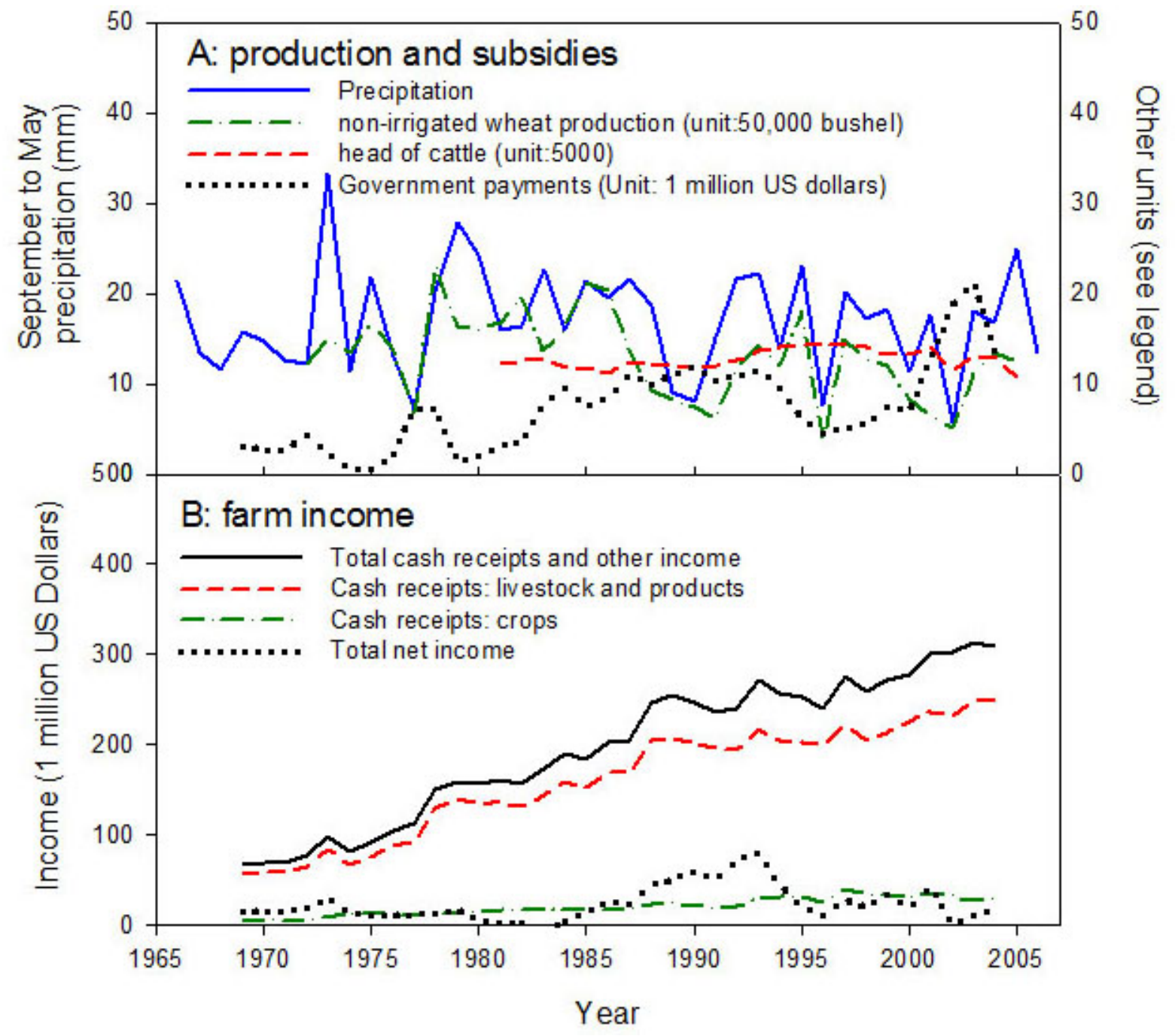

Evans and Belnap 1999, Belnap and Eldridge 2003). Extractive industries on the Colorado Plateau, especially those that rely on rainfall, have always been a marginal enterprise (including in prehistoric times), prone to overuse, and in the long-run, unsustainable. Even with the benefit of everincreasing external subsidies, farming and ranching are currently declining in this region (Fig. 6). By contrast, industries largely independent of regional rainfall, such as the service and tourist sectors, have greatly expanded, both in relative and absolute terms. 
Fig. 5. Ecologic and economic reserves compete for net primary productivity. The division of net primary productivity is regulated by the extraction effort ("control loop" 1). Increasing extractive effort will reduce ecological "plough-back" and diminish ecological reserves. Reduced ecological reserves will reduce rain-use efficiency ("control loop" 2) and future primary productivity. Economic reserves are bolstered by external subsidies, e.g., government payments. Critical to sustainable management is the nature of the feedback of economic reserves on extractive effort. A positive feedback will lead to overexploitation, a negative feedback may promote system resilience (see text for details).

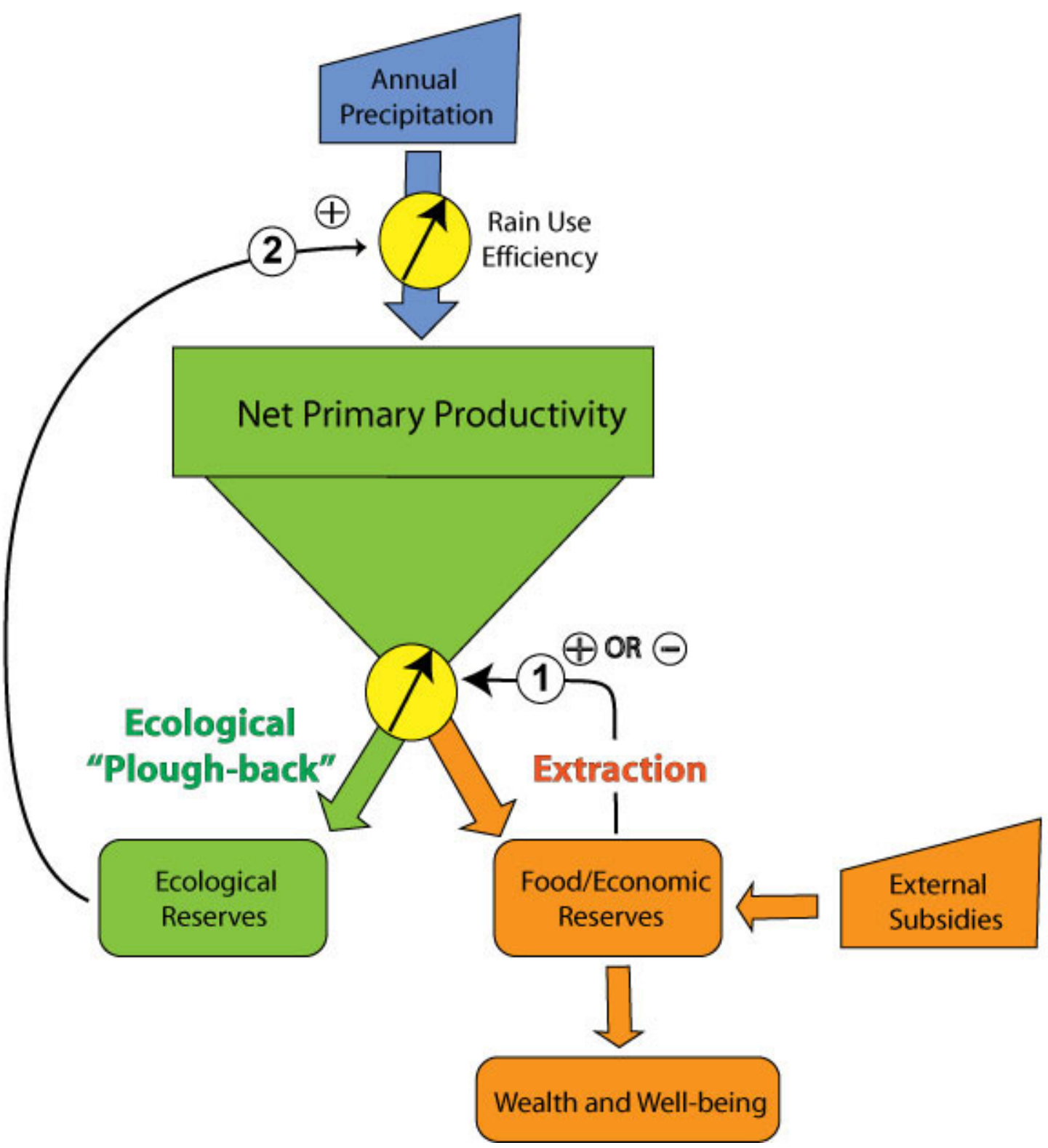


Fig. 6. A: population, employment, and tourism trends on the Colorado Plateau. B: Employment trends by sector. (Data sources: U.S. Department of Commerce, Bureau of Economic Analysis and National Park Service).

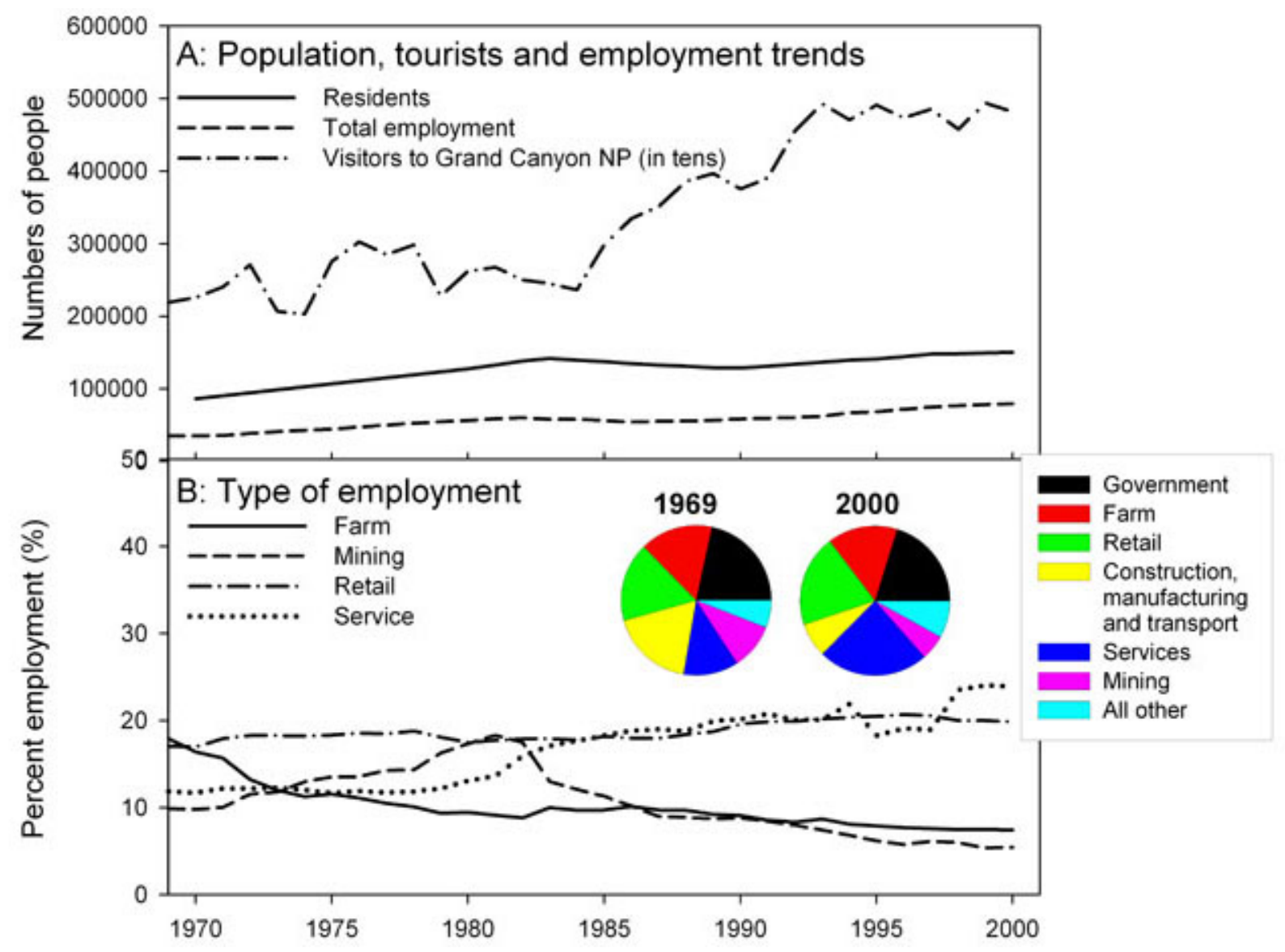

\section{THE FUTURE OF THE COLORADO PLATEAU}

The uncertainty surrounding future climate scenarios is of great concern in this region. The expected increase in both average and extreme temperatures will likely result in less soil moisture and thus greater plant stress, even if precipitation patterns remained constant. Warming at night will increase respiration losses of plants (Alward et al. 1999), which may increase rates of mortality. For example, using warming lamps, we have seen $20 \%$ mortality in the summer-active $\mathrm{C}_{4}$ galleta grass (Belnap, unpublished). Drought combined with increased temperatures results in far greater and more widespread tree mortality than drought alone
(Breshears 2006). The long-term effects of climate change on the ecosystems of the Colorado Plateau will also depend on the process of drought recovery, in which BSCs play a major role.

Unfortunately, BSCs may be the biggest losers in this climate-change century: a recent field study showed that the dominant BSC lichen Collema tenax (the main source of $\mathrm{N}$ for this ecosystem) declined from $19 \%$ in 1996 to $2 \%$ after 6 years of record-breaking high summer temperatures (Belnap et al. 2006).

Although the 2002 drought has waned, it is possible that the Colorado Plateau is experiencing a shift into a negative cycle of the PDO, which would continue 
to reduce winter precipitation for 20-30 years (Hereford et al. 2002). This will result in sustained losses in primary productivity and diminished ability of BSCs to recover from the stresses of summer (Belnap et al. 2006). Particularly damaging would be a shift toward less winter and relatively more summer precipitation. Experiments showed a significant decline in photosynthetic rates and pigment production in Collema and cyanobacterial crusts when exposed to an increased frequency of small rainfall events during summer (Belnap et al. 2004). An ongoing precipitation manipulation study shows an increase in mortality of the dominant moss Syntrichia caninervis under these conditions as well (Belnap, unpublished). If both summer and winter precipitation are reduced, the loss of lichens and mosses would likely be exacerbated. These potentially highly negative impacts of climate changes on BSCs, intensified by increasing levels of human use, will likely further diminish BSC cover, slow ecosystem recovery from drought, increase soil erosion rates, and generally accelerate the desertification of the Colorado Plateau.

\section{CONCLUSION}

The Colorado Plateau ecosystems developed under conditions of low total and highly variable precipitation, combined with low disturbance frequencies either from grazing or fire in the lower elevation scrublands. Due to the low productivity of this region, recovery from disturbance is slow, probably in the order of several hundred years. This has resulted in ecosystems being highly vulnerable to changes in land use, and in turn, has left land users with a low intrinsic buffering capacity for climatedependent fluctuations in yield. In medieval times, a decadal megadrought, perhaps combined with overuse of natural resources, led to the abandonment of the Colorado Plateau by the first human settlers. The comparatively wet and stable conditions that ushered in the Anglo occupation of the Colorado Plateau, together with the introduction of external subsidies, including water subsidies and the development of climate-independent industries, have allowed more humans than ever before to live on the Colorado Plateau. Nevertheless, economic statistics indicate that the many livelihoods that still depend on rainfall are in decline. Now, climate models predict a new cycle of megadroughts to commence in the second half of this century. If realized, it is unlikely that even today's economic buffering capacities will allow the long-term persistence of extractive industries on the Colorado Plateau, as ecosystems are already challenged by historic overuse. The alternative is an increased reliance on other forms of income, which are less dependent on rainfall inputs. This change is already occurring, as many families that traditionally relied solely on livestock or farming for income have begun to explore other sources of income.

Responses to this article can be read online at:

http://www.ecologyandsociety.org/volXX/issYY/artZZ/responses/

\section{LITERATURE CITED}

Adams A. 2005. Rocky mountain elk. Wildlife Notebook Series No. 12, Utah Division of Wildlife Resources, Salt Lake City, Utah. (online) URL: htt p://www.wildlife.utah.gov/publications/pdf/elknew. pdf.

Adams D. K., and A. C. Comrie. 1997. The North American monsoon. Bulletin of the American Meteorological Society 78:2197-2213.

Allen, C. D., and D. D. Breshears. 1998. Droughtinduced shift of a forest-woodland ecotone: rapid landscape response to climate variation. Proceedings of the National Academy of Science 95:1483914842.

Alward, R. D., J. K. Detling, and D. G. Milchunas. 1999. Grassland vegetation changes and nocturnal global warming. Science 283:229-231.

Alzerreca-Angelo, H., E. W. Schupp, and S. G. Kitchen. 1998. Sheep grazing and plant cover dynamics of a shadscale community. Journal of Range Management 51:214-222.

Anderson, R. S., J. L. Betancourt, J. I. Mead, R. H. Hevly, and D. P. Adam. 2000. Middle- and lateWisconsin paleobotanic and paleoclimatic records from the southern Colorado Plateau, USA. Paleogeography, Paleoclimatology, Paleoecology 155:31-57.

Axtell, R. L., J. M. Epstein, J. S. Dean, G. J. Gumerman, A. C. Swedlund, J. Harburger, S. Chakravarty, R. Hammond, J. Parker, and $M$. Parker. 2002. Population growth and collapse in a multiagen model of the Kayenta Anasazi in Long 
House Valley. Proceedings of the National Academy of Science 99:7275-7279.

Barger, N. N., J. Belnap, D. S. Ojima, and A. Mosier. 2005. NO gas loss from biologically crusted soils in Canyonlands National Park, Utah. Biogeochemistry 75:373-391.

Barlow, M., S. Nigam, and E. H. Berbery. 1998. Evolution of the North American monsoon system. Journal of Climate 11:2238-2257.

Belnap, J. 1995. Surface disturbances: their role in accelerating desertification. Environmental Monitoring and Assessment 37:39-57.

Belnap, J. 2002. Nitrogen fixation in biological soil crusts from southeast Utah, USA. Biology and Fertility of Soils 35:128-135.

Belnap, J. 2003a. Factors influencing nitrogen fixation and nitrogen release in biological soil crusts. Pages 241-261 in J. Belnap and O. L. Lange, editors. Biological soil crusts: structure, function and management. Springer Verlag, Berlin, Heidelberg, Germany; New York, New York, USA.

Belnap, J. 2003b. Microbes and microfauna associated with biological soil crusts. Pages 167174 in J. Belnap and O. L. Lange, editors. Biological soil crusts: structure, function, and management. Springer Verlag, Berlin, Heidelberg, Germany; New York, New York, USA.

Belnap, J., and D. J. Eldridge. 2003. Disturbance and recovery of biological soil crusts. Pages 363383 in J. Belnap and O. L. Lange, editors. Biological soil crusts: structure, function, and management. Springer Verlag, Berlin, Heidelberg, Germany; New York, New York, USA.

Belnap, J., and J. S. Gardner. 1993. Soil microstructure in soils of the Colorado Plateau: the role of the cyanobacterium Microcoleus vaginatus. Great Basin Naturalist 53:40-47.

Belnap, J., R. Prasse, and K. T. Harper. 2003. Influence of biological soil crusts on soil environment and vascular plants. Pages 281-300 in J. Belnap and O. L. Lange, editors. Biological soil crusts: structure, function, and management. Springer Verlag, Berlin, Heidelberg, Germany; New York, New York, USA.
Belnap, J., S. L. Phillips, and M. E. Miller. 2004. Response of desert biological soil crusts to alterations in precipitation frequency. Oecologia 141:306-316.

Belnap, J., S. L. Phillips, and T. Troxler. 2006. Soil lichen and moss cover and species richness can be highly dynamic: the effects of invasion by the annual exotic grass Bromus tectorum, precipitation, and temperature on biological soil crusts in SE Utah. Applied Soil Ecology 32:63-76.

Belsky, A. J., and J. L. Gelbard. 2000. Livestock grazing and weed invasions in the arid west. Oregon Natural Desert Association. Bend, Oregon, USA.

Betancourt, J. L. 1990. Late Quaternary biogeography of the Colorado Plateau. Pages 259292 in J. L. Betancourt, T. R. van Devender, and P. S. Martin, editors. Packrat middens: the last 40000 years of biotic change. University of Arizona Press, Tucson, Arizona, USA.

Bowers, J. E., R. H. Webb, and R. J. Rondeau. 1995. Longevity, recruitment and mortality of desert plants In Grand-Canyon, Arizona, USA. Journal of Vegetation Science 6:551-564.

Breshears, D. D. 2006. The grassland-forest continuum: trends in ecosystem properties for woody plant mosaics? Frontiers in Ecology and the Environment 4:96-104.

Caldwell, M. M. 1985. Cold desert. Pages 198-212 in B. F. Chabot and H. A. Mooney, editors. Physiological ecology of North American plant communities. Chapman and Hall, New York, New York, USA.

Cayan, D.R., K. T. Redmond, and L. G. Riddle. 1999. ENSO and hydrologic extremes in the western United States. Journal of Climate 12:2881-2893.

Cole, K. L., N. Henderson, and D. S. Shafer. 1997. Holocene vegetation and historic grazing impacts at Capitol Reef National Park reconstructed using packrat middens. Great Basin Naturalist 57:315326.

Coltrain, J. B., and S. W. Leavitt. 2002. Climate and diet in Fremont prehistory: economic variability and abandonment of maize agriculture in the Great Salt Lake Basin. American Antiquity 67:453-485. 
Comstock, J. P., and J. R. Ehleringer. 1992. Plant adaptation in the Great-Basin and Colorado Plateau. Great Basin Naturalist 52:195-215.

Connin, S. L., J. Betancourt, and J. Quade. 1998. Late Pleistocene C-4 plant dominance and summer rainfall in the southwestern United States from isotopic study of herbivore teeth. Quaternary Research 50:179-193.

Cook, E. R., C. A. Woodhouse, C. M. Eakin, D. M. Meko, and D. W. Stahle. 2004. Long-term aridity changes in the western United States. Science 306:1015-1018.

Cook, E. R., R. Seager, M. A. Cane, and D. W. Stahle. 2007. North American drought: reconstructions, causes, and consequences. Earth-Science Reviews 81: 93-134.

Cottam, W.P. 1948. The impact of man on the flora of the Bonneville basin. Pamphlet A55. Special Collections, Utah State University Library, Logan, Utah, USA.

D'Arrigo, R. D., and G. C. Jacoby. 1991. A 1000year record of winter precipitation from northwestern New Mexico, USA: a reconstruction from tree-rings and its relation to El Nino and the Southern Oscillation. Holocene 1:95-101.

Dregne, H. E. 1983. Desertification of arid lands. Harwood Academic Publishers, New York, New York, USA.

Ehleringer, J. R., S. L. Phillips, W. F. S. Schuster, and D. R. Sandquist. 1991. Differential utilization of summer rains by desert plants, implications for competition and climate change. Oecologia 88:430-434.

Evans, R. D, and J. Belnap. 1999. Long-term consequences of disturbance on nitrogen dynamics in an arid ecosystem. Ecology 80:150-160.

Evans, R. D., and J. R. Ehleringer. 1993. A break in the nitrogen-cycle in aridlands - evidence from delta-N-15 of soils. Oecologia 94:314-317.

Fernandez, O. A., and M. M. Caldwell. 1975. Phenology and dynamics of root growth of three cool semi-desert shrubs under field conditions. Journal of Ecology 63:703-714.
Fernandez, D., J. Neff, J. Belnap, and R. Reynolds. 2006. Soil respiration in the cold desert environment of the Colorado Plateau (USA): Abiotic regulators and thresholds. Biogeochemistry 78:247-265.

Firmage, R. A. 1996. A history of Grand County. Utah Centennial County History Series, Utah State Historical Society and Grand County, Salt Lake City, Utah.

Flanagan, L. B., J. R. Ehleringer, and J. D. Marshall. 1992. Differential uptake of summer precipitation among co-occurring trees and shrubs in a pinyon-juniper woodland. Plant, Cell and Environment 15:831-836.

Gebauer, R. L. E., and J. R. Ehleringer. 2000. Water and nitrogen uptake patterns following moisture pulses in a cold desert community. Ecology 81:1415-1424.

George, D. B., B. A. Roundy, L. L. St. Clair, J. R. Johansen, G. B. Schaalje, and R. L. Webb. 2003. The effects of microbiotic soil crusts on soil water loss. Arid Land Research and Management 17:113 125.

Gray, S. T., J. L. Betancourt, C. L. Fastie, and S. T. Jackson. 2003. Patterns and sources of multidecadal oscillations in drought-sensitive treering records from the central and southern Rocky Mountains. Geophysical Research Letters 30 (6):316. doi:10.1029/2002GL016154.

Guevara, J. C., C. R. Stasi, O. R. Estevez, and H. N. Le Houerou. 2000. $\mathrm{N}$ and $\mathrm{P}$ fertilization on rangeland production in midwest Argentina. Journal of Range Management 53:410-414.

Harrington, J. A. Jr., R. S. Cerveny, and R. C. Balling, Jr. 1992. Impact of the southern oscillation on the North American southwest monsoon. Physical Geography 13:318-330.

Hart, R. H., and W. A. Laycock. 1996. Repeat photography on range and forest lands in the western United States. Journal of Range Management 49:60-67.

Hereford, R., and R. H. Webb. 1992. Historic variation of warm-season rainfall, southern Colorado Plateau, southwestern U.S.A. Climatic Change 22:239-256. 
Hereford, R., R. H. Webb, and S. Graham. 2002. Precipitation history of the Colorado Plateau Region, 1900-2000. U.S. Geological Survey Fact Sheet 119-02. (online) URL: http://geopubs.wr.usgs. gov/fact-sheet/fs119-02/.

Hess, K. Jr., and J. L. Holechek. 1995. Policy roots of land degradation in the arid region of the United States: an overview. Environmental Monitoring and Assessment 37:123-141.

Kitzberger, T., P. M. Brown, E.K. Heyerdahl, T. W. Swetnam, and T. T. Veblen. 2007. Contingent Pacific-Atlantic Ocean influence on multicentury wildfire synchrony over western North America, Proceedings of the National Academy of Sciences 104:543-548.

Lange, O. L. 2003. Photosynthesis of soil-crust biota as dependent on environmental factors. Pages 217-240 in J. Belnap and O. L. Lange, editors. Biological soil crusts: structure, function and management. Springer Verlag, Berlin, Heidelberg, Germany; New York, New York, USA.

Lange, O. L., J. Belnap, and H. Reichenberger. 1998. Photosynthesis of the cyanobacterial soilcrust lichen Collema tenax from arid lands in southern Utah, USA: role of water content on light and temperature responses of $\mathrm{CO}_{2}$ exchange. Functional Ecology 12:195-202.

Lange, O. L., J. Belnap, H. Reichenberger, and A. Meyer. 1997. Photosynthesis of green algal soil crust lichens from arid lands in southern Utah, USA: role of water content on light and temperature responses of $\mathrm{CO}_{2}$ exchange. Flora 192:1-15.

Lange, O. L., T. G. A. Green, H. Reichenberger, and A. Meyer. 1996. Photosynthetic depression at high thallus water contents in lichens: concurrent use of gas exchange and fluorescence techniques with a cyanobacterial and a green algal Peltigera species. Botanica Acta 109:43-50.

Larson, D. O., and J. Michaelsen.1990. Impacts of climate variability and population growth on Virgin Branch Anasazi cultural developments. American Antiquity 55:227-249.

Le Houérou, H. N. 1984. Rain use efficiency: a unifying concept in arid-land ecology. Journal of Arid Environment 7:213-247.
Lin, G., S. L. Phillips, and J. R. Ehleringer. 1996. Monsoonal precipitation responses of shrubs in a cold desert community on the Colorado Plateau. Oecologia 106:8-17.

Mack, R. N., and J. N. Thompson. 1982. Evolution in steppe with few large, hooved mammals. The American Naturalist 119:757-773.

Mantua, N. J., and S. R. Hare. 2002. The Pacific decadal oscillation. Journal of Oceanography 58:35-44.

McPherson, R. S. 1995. A history of San Juan County: in the palm of time. Utah Centennial County History Series, Utah State Historical Society and San Juan County, Salt Lake City, Utah.

Meko, D., C.W. Stockton, and W. R. Bogess. 1995. The tree-ring record of severe sustained drought. Water Resources Bulletin 31:789-801.

Neff, J. C., R. L. Reynolds, J. Belnap, and P. Lamothe. 2005. Multi-decadal impacts of grazing on soil physical and biogeochemical properties in southeast Utah. Ecological Applications 15: 87-95.

Nelson, M. C., and G. Schachner. 2002. Understanding abandonments in the North American Southwest. Journal of Archaeological Research 10:167-206.

Ni, F., T. Cavazos, M. K. Hughes, A. C. Comrie, and G. Funkhouser. 2002. Cool-season precipitation in the southwestern USA since AD 1000: comparison of linear and nonlinear techniques for reconstruction. International Journal of Climatology 22:1645-1662.

Noy-Meir, I. 1973. Desert ecosystems: environment and producers. Annual Review of Ecology and Systematics 4:25-41.

Paul, E. A., and F. E. Clark. 1996. Soil microbiology and biochemistry, second edition. Academic Press, San Diego, California, USA.

Petersen, K. L. 1994. A warm and wet little climatic optimum and cold and dry little ice age in the southern Rocky Mountains, USA. Climate Change 26:243-269.

Powell, S., and F. E. Smiley. 2002. Ten thousand years on Black Mesa. University of Arizona Press, Tucson, Arizona, USA. 
Redman, C. L. 1999. Human impact on ancient environments. University of Arizona Press, Tucson, Arizona, USA.

Seager, R., M. Ting, I. Held, Y. Kushnir, J. Lu, G. Vecchi, H.-P. Huan, N. Harnik, A. Leetmaa, N.C. Lau, C. Li, J. Velez, and N. Naik. 2007. Model projections of an imminent transition to a more arid climate in southwestern North America. Science 316:1181-1184.

Salzer, M. W., and K. F. Kipfmueller. 2005. Reconstructed temperature and precipitation on a millennial timescale from tree-rings in the southern Colorado Plateau, USA. Climate Change 70:65487.

Schwinning, S., K. Davis, L. Richardson, and J. R. Ehleringer. 2002. Deuterium enriched irrigation suggests three forms of pulse use in perennial species of the Colorado Plateau. Oecologia 130:345-355.

Schwinning, S., and J. R. Ehleringer. 2001. Water use trade-offs and optimal adaptations to pulsedriven arid ecosystems. Journal of Ecology 89:464480 .

Schwinning, S., and O. E. Sala. 2004. Hierarchy of responses to resource pulses in and and semi-arid ecosystems. Oecologia 141:211-220.

Schwinning, S., B. I. Starr, and J. R. Ehleringer. 2003. Dominant cold desert plants of the Colorado Plateau do not partition rain by rainfall size. Oecologia 136:252-260.

Schwinning, S., B. I. Starr, N. J. Wojcik, M. E. Miller, J. E. Ehleringer, and R. L. Sanford. 2005. Effects of nitrogen deposition on an arid grassland in the Colorado plateau cold desert. Rangeland Ecology and Management 58:565-574.

Stahle, D. W., E. R. Cook, M. K. Cleaveland, M. D. Therrell, D. M. Meko, H. D. Grissino-Mayer, E. Watson, and B. H. Luckman. 2000. Tree-ring data document 16th century megadrought over North America, EOS 81:124-125.

Swetnam, T. W., and J. L. Betancourt.1998. Mesoscale disturbance and ecological response to decadal climatic variability in the American southwest. Journal of Climate 11:3128-3147.
Thurow, T. L., and C. A. Taylor. 1999. Viewpoint: the role of drought in range management. Journal of Range Management 52:413-419.

van Vuren, D., and F. C. Dietz. 1993. Evidence of Bison bison in the Great Basin. Great Basin Naturalist 53:318-319.

Warren, S. D. 2003. Biological soil crusts and hydrology in North American deserts. Pages 327337 in J. Belnap and O. L. Lange, editors. Biological soil crusts: structure, function and management. Springer Verlag, Berlin, Heidelberg, Germany; New York, New York, USA.

Webb, R. H., J. Belnap, and J. S. Weisheit. 2004. Cataract Canyon: a human and environmental history of rivers in Canyonlands. University of Utah Press, Salt Lake City, Utah, USA.

Webb, R. H., G. J. McCabe, R. Hereford, and C. Wilkowske. 2004. Climatic fluctuations, drought, and flow on the Colorado River. U.S. Geological Survey Fact Sheet 119-02.

West, A. G., K. R. Hultine, K. Burtch, and J. R. Ehleringer. 2007a. Seasonal variations in moisture use in a piñon-uniper woodland. Oecologia 153:787-798.

West, A. G., K. R. Hultine, T. L. Jackson, and J. R. Ehleringer. 2007b. Differential summer moisture use by Pinus edulis and Juniperus osteosperma reflects contrasting hydraulic patterns. Tree Physiology 27:1711-1720.

West, A. G., K. R. Hultine, J. S. Sperry, S. E. Bush, and J. R. Ehleringer. 2008. Transpiration and hydraulic strategies in a piñon-juniper woodland. Ecological Applications: in press.

West, N. E. 1988. Intermountain deserts, shrub steppes, and woodlands. North American Terrestrial Vegetation. Pages 210-230 in M. G. Barbour and W. D. Billings, editors. North American Terrestrial Vegetation. Cambridge University Press, New York, New York, USA.

Westerling, A. L., H. G. Hidalgo, D. R. Cayan, and T. W. Swetnam. 2006. Warming and earlier spring increase western U.S. forest wildfire activity. Science 313:940-943. 
Wilkowske, C. D., D. V. Allen, and J. V. Phillips. 2003. Drought conditions in Utah during 19992002: a historical perspective. U.S. Geological Survey Fact Sheet 037-03.

Williams, D. G., and J. R. Ehleringer. 2000. Intraand interspecific variation for summer precipitation use in pinyon-juniper woodlands. Ecological Monographs 70:517-537.

Zhang, Y., J. M. Wallace, and D. S. Battisti. 1997. ENSO-like interdecadal variability: 1900-93. Journal of Climate 10:1004-1020. 